\title{
Türkçe Öğretmenlerinin Okuma Stratejileri Bilişsel Farkındalık Becerilerini Kullanma Düzeylerine İlişkin Görüşleri
}

\section{The Views Of Turkish Teachers On The Level Of Using Their Cognitive Awareness Skills Of Reading Strategies}

\author{
Selma ERDA $\breve{G}$ TOKSUN \\ Kafkas Üniversitesi Eğitim Fakültesi Sosyal Bilimler ve Türkçe Eğitimi Bölümü, Türkçe Eğitimi A.B.D., \\ Kars \\ selma_erdagi@hotmail.com
}

\begin{abstract}
$\ddot{O z e t}$
Okumada temel amaç okuduğunu anlama ve bu yolla anlama yeteneğini geliştirmedir. Anlamayı sağlamak için ise bir dizi zihinsel işlem gerekmektedir. Okuma amacına ve içinde bulunulan koşullara göre okuma teknikleri birtakım farklılıklar göstermektedir. Bu özellikler dikkate alınarak öğrencilere amaca göre okuma becerisi kazandırılmalıdır. Okunan metinden tam ve doğru anlam çıkarma okuldaki öğrenmelerin de temelini oluşturmaktadır. Etkili okuma, akademik malzemenin içeriğinin kavranması ve öğrenmesi açısından oldukça önemlidir. Okul yaşantısı ve sosyal yaşantıda bireyler çeşitli yazılı malzemeleri okuyup anlamak durumundadırlar. Okunanın basit düzeyde anlaşılması, sınırlı sayıdaki temel düşünceyi bulma, özet çıkarma ve benzer sorulara yanıtlar bulma istenen okuma düzeyini elde etmek için yetersiz kalmaktadır. Bu araştırma, Türkçe öğretmenlerinin, öğrencilere okuma-anlama becerisini kazandırmak için sınıf ortamında ve sınıf dışında kullandıkları okuma stratejileri bilişsel farkındalık becerilerini tespit etmek amacıyla yapılmıştır. Bu çalışma nitel veri toplama tekniklerinden görüşme yöntemi kullanılarak yapılmıştır. Araştırmanın çalışma grubunu 2012-2013 yılında, Kars ilinde Millî Eğitim Bakanlığına bağlı ortaokullarda görev yapan Türkçe öğretmenleri oluşturmaktadır. Çalışma için uzman görüşleri dikkate alınarak yarı yapılandırılmış bir görüşme formu hazırlanmıştır. Öğretmenlerle yapılan görüşmeler sonucunda elde edilen veriler, yarı yapılandırılmış görüşme formu ile toplanmış ve içerik analizi yöntemiyle incelenmiştir. Araştırma sonuçlarına göre Türkçe öğretmenlerinin öğrencilerin okuma stratejileri bilişsel farkındalık becerilerini geliştirmeye yönelik sınıf içinde ve sınıf dışında etkinlikler yaptıkları fakat bu etkinliklerin öğrencilerin okuma stratejileri bilişsel farkındalık becerilerini geliştirecek yeterlilikte olmadığı tespit edilmiştir.
\end{abstract}

Anahtar Kelimeler: Okuma Eğitimi, Anlama, Okuma Stratejileri, Türkçe Eğitimi.

Abstract

The main purpose of reading is to understand what you read and to improve your ability to understand in this way. However, a series of cognitive process is required to provide understanding. Reading techniques show some differences in accordance with the purpose of reading and the conditions. Reading skill should be brought to students based on purpose by considering these features. Inferring the exact and accurate meaning from the text read constitutes the basis for the learning at school. Effective reading is considerably important in terms of comprehending and learning the content of academic materials. Individuals read and understand various written materials in school and social lives. Understanding what is read at simple level, finding the main idea in limited number, summarizing and findings answers to similar questions remain insufficient to achieve the level of reading desired. The aim of this study is to determine the cognitive awareness skills of reading strategies used by Turkish teachers in and outside classroom environment for the students to acquire readingunderstanding skill. This study was conducted by using interview technique among qualitative data collection techniques. The sample group of the study consisted of Turkish teachers working in secondary schools affiliated with Ministry of National Education in the province of Kars between 2012 and 2013. By considering expert opinions, a semi-structured interview form was prepared for the study. The data obtained as a result of the interviews with the teachers were collected by using semi-structured interview form and analyzed via content analysis technique. According to the results of the study, it was determined that Turkish teachers carried out activities in and outside the class for improving reading strategies cognitive awareness skills of the students; however, these activities were not competent to develop the students' cognitive awareness skills of reading strategies.

Keywords: Reading education, Understanding, Reading Strategies, Turkish Education.

\footnotetext{
${ }^{2}$ Bu çalışma 2015 yılında Necmettin Erbakan Üniversitesi Ahmet Keleşoğlu Eğitim Fakültesi Eğitim Bilimleri Enstitüsünde kabul edilen Türkçe Öğretmenlerinin Okuma Stratejileri Bilişsel Farkındalık Becerilerini Kullanma Düzeylerine İlişkin Bir Araştırma (Kars İli Örneği) başlıklı Doktora Tezinden oluşturulmuştur.
} 


\section{GíRiş}

Okumanın temel amacı olan anlamayı sağlamak için bir dizi zihinsel işlem gerekmektedir. Anlama ile sonuçlanmayan bir okuma etkinliği gerçek amacına ulaşmamış demektir. Anlama bireyin yazılı ve basılı işaretlerin temsil ettiği manayı kavramasıyla mümkün olmaktadır. Okumada en önemli husus anlamadır ve anlam kelimelerde ve onların altında yatan anlamlarda saklıdır. İyi bir okuma faaliyeti ancak bize verilmek istenen mesajın doğru anlaşılmasıyla gerçekleştirilir. Bir yazıdaki kelimeleri anlama olmadan sadece seslendirmek okuma değildir. Bunun için metinlerde yazılanlar değil anlatılmak istenenler önemlidir. Anlama, metinde iletilmek isteneni doğru olarak algılamak ve yorumlamaktır. Anlama gerçekleşmişse okuma etkinliği başarılla tamamlanmıştır. Buna göre okuma, temel niteliği ile bir anlama süreci anladığını değerlendirme sürecidir.

Okuma eylemi ilk önce metni tanıma ve okuduğu metinde iletilmek istenen anlamı tam ve doğru almadır. Okumak, bilginin yerini bulmak ve yazının planını çözmektir. Ardından metni yorumlayabilmek ve eleştirebilmektir. Metindeki bilgileri ön bilgilerle ve tecrübelerle birleştirmek, ileriye dönük tahminlerde bulunmak ve fikirleri organize etmek okumanın temel amaçları arasındadır. Yorumlamanın ardından metni; dil, konu, amaç, gerçeklik, değer ve yeterlilik bakımından değerlendirmek iyi bir okuyucunun yapması gerekenlerdir.

Bireyin okuduğundan anladığı da yaşadığı sosyal çevre ve aile yaşantısıyla doğrudan etkilidir. Bireyde okuma ilgisinin uyanması, okuma alışkanlığı kazanma ve bu alışkanlığı yaşam biçimine dönüştürme tamamen yetişme tarzı ve ortamıyla ilgilidir.

Okumada temel amaç okuduğunu anlama ve bu yolla anlama yeteneğini geliştirmedir. Okuduğunu anlama; yazılı bir materyalden anlam çıkarmayı ve ayrıntıları kavramayı gerektiren, daha ilköğretim düzeyinden itibaren öğrencilere kazandırılması gereken temel dil becerilerinden biridir (Rose ve diğ. 2000: 55, akt. Epçaçan, 2009: 210). tanımlamıştır:

Okuduğunu anlama süreçlerini tüm boyutları ile kapsamlı bir şekilde Irwin (1991: 6) şu şekilde

1. Mikro Süreçler: Üniteyi küçük parça ya da cümlelere ayırarak anlamayı içerir. Böylece tüm metni bir bütün olarak parçaları ile birlikte anımsayabiliriz. Burada önemsiz bilgileri ayıklama işimizi kolaylaştırır.

2. Bütünleyici Süreçler: Okuma parçalarındaki ipuçlarının ve ilişkilerin anlaşılması önemlidir. İpuçlarının ve metinler arasındaki bağlantıların anlaşılması bütünleyici süreç olarak adlandırilır.

3. Makro Süreçler: Elde edilen bilgilerin bir düzen içinde hatıllanması ve özet olarak zihinde belirmesi, makro anlama süreçlerini gerektirir.

Organize Etme: Karışık içeriği anlamak ve hatırlamak zordur. Bu nedenle bu içeriği belirlemek, olayı sırasıyla bilmek, bunların içindeki tutarlılık, olay, sonuç ve dönüt gibi basamaklar bilgileri organize etmede kullanılabilir.

4. Ayrıntıları Belirleme Süreci: $\mathrm{Bu}$ süreçler bizim ne bildiğimizi, ne yapmak istediğimizi, öğrendiklerimizi uygulama gücümüzü, deneyimlerimizi, tutumlarımızı, inançlarımızı ve değerlerimizi ortaya koymamızı sağlar. Bu süreçlerde önceden tahmin etme ve şema (harita) çıkarma, üst düzey düşünme süreçleri için önemli adımlardır. $\mathrm{Bu}$ haritada olay, kişi, nesne vb. boyutlar kullanılabilir. Önemsiz kısımlar atılır. Bu bireysel öğrenme, düşünme ve hatırlamayı geliştirir.

5. Bilişsel Farkındalık Anlama Süreçleri: Birçok kişi; fakında olsa da olmasa da okuduğunu anlayıp-anlamadığını izleme, kendi düşünme ve öğrenme yollarını izleme ve ders çalışma becerileri belirleme gibi birçok bilişsel farkındalık becerisini kullanır. Başlangıçta kişinin dikkatini vermesi, tutum geliştirmesi, ne bildiğini kontrol etmesi ve öğreneceği şeyi başarması için o şeye odaklanması gerekmektedir. Sonra bir düşünme stratejisi planlayıp, yapacağı işleri önceden belirlemelidir. Bu stratejiyi kullandığında; amacına ulaşma derecesini kontrol etmeli, en son elde ettiği bilgi ile ilk bildiğini karşılaştırıp, gerekiyorsa planda düzenleme yapmalıdır. Bir öğrenci bilişsel farkındalık stratejilerini sistematik olarak kullandığında; o kişinin okuduğunu anlama becerisi böylece gelişmektedir (Akt. Gelen, 2003: 62).

Bamberger (1990: 11), okuma eğitiminin amaçlarını değerlendirerek şu şekilde sıralamıştır:1) Bireylerin 
okuma kapasitelerini son noktasına kadar kullanmaya özendirmek; Bu onların kendi kendilerini anlamalarında rehberlik edecektir. 2) Okumayı, öğrenme ve araştırmanın yanında rahatlamak için de yeterli biçimde kullanmak. 3) Öğrencilerin okuma ilgilerini devamlı geliştirmek.4) Değişik türde ve değişik amaçlarla okumaya zemin hazırlayacak bir okuma yaklaşımı oluşmasını sağlamak.

Genellikle okumanın öneminin Türkçe ve Türk Dili ve Edebiyatı derslerinde dile getirildiğini ve okuma etkinliğinin sadece bu derslerin sınırlılıkları içerisindeymiş gibi bir anlayışa hâkim olunduğunu söyleyen Aytaş (2003: 155), okuma eğitiminin bütün dersler içinde üzerinde önemle durulması gereken bir beceri olduğuna dikkat çekmiş ve eğitim süreci içerisinde okuma gelişiminin beş aşamada gerçekleştiğini söylemiştir:

1. Temel eğitim öncesi ve temel eğitimin ilk yıllarını kapsayan okumayı öğrenmek için gerekli yeteneğin elde edildiği dönem. Bu dönem öğrencinin okumaya istekli olmasını hazırlayan dönemdir.

2. Temel eğitimin ilk aşamasını oluşturan okumaya başlangıç dönemi. Bu dönemde çocuklar artık tek başına okuma yapacak düzeye gelmişlerdir.

3. Okuma isteği ve alışkanlığının geliştiği dönem. Genellikle temel eğitimin 2. ve 3. sınıflarına rastlar.

4. Okuma deneme ve imkânlarının hızla yayıldığı, okumada güç ve üstünlüğün elde edildiği dönem. Genellikle temel eğitimin $4-5$ ve 6 . sınıflarına rastlamaktadır. Bu dönemin belirgin niteliği, öğrencinin kültürünü zenginleştiren geniş bir okumadır.

5. Okuma ilgi ve alışkanlıklarını, okumada zevk almanın inceldiği evredir ki temel eğitimin ikinci ve orta öğrenim dönemleriyle yüksek öğrenimin ilk yıllarına rastlamaktadır. Bu evrede okuma zevki diye adlandırılan duygunun zamanında gelişmesi önemlidir.

Okunan metinden tam ve doğru anlam çıkarma okuldaki öğrenmelerin de temelini oluşturmaktadır. Etkili okuma, akademik malzemenin içiriğinin kavranması ve öğrenmesi açısından oldukça önemlidir. Okul yaşantısı ve sosyal yaşantıda bireyler çeşitli yazılı malzemeleri okuyup anlamak durumundadırlar. Okunanın basit düzeyde anlaşılması, sınırlı sayıdaki temel düşünceyi bulma, özet çıkarma ve benzer sorulara yanıtlar bulma istenen okuma düzeyini elde etmek için yetersiz kalmaktadır. Bu yüzden son yıllarda yapılan araştırmalar anlama becerisini geliştirecek stratejiler üzerinde yoğunlaşmaktadır. Okuduğunu anlama düşünme ile ilgilidir.

\section{Düşünme ve Boyutlart Nelerdir?}

Düşünme; "duyum ve izlenimlerden, tasarımlardan ayrı olarak aklın bağımsız ve kendine özgü durumu; karşılaştırmalar yapma, ayırma, birleştirme, bağlantıları ve biçimleri kavrama yetisi.” (TDK, 2011: 743) olarak tanımlanmaktadır.

Düşünmenin ne olduğunu anlamak için düşünmenin boyutlarına bakmak ve boyutlarını açıklamak gerekmektedir. Marzano, Brandt, Hugles, Jones, Rankin ve Suhar’a (1991) göre düşünmenin tanımlanan beş boyutu şunlardır: (Akt. Doğanay, 1996: 26)

1. Eleştirel ve Yaratıcı Düşünme (Critical and Creative Thinking), 2. Düşünme Süreçleri (Thinking Processes), 3. Temel Düşünme Becerileri (Core Thinking Skills),4. Konu Alanı Bilgisi (Content Area Knowledge), 5.Bilişsel Farkındalık (Metacognition)

Gelen'e (2003: 24) göre bilişsel farkındalık bir düşünme sistematiğidir. Dikkatini konu üzerine verme, kendini o iş ya da konuya adama, iş ya da konu hakkında gerekli tutum geliştirme, iş ya da konuyu zihinde planlama, o planın nasıl gittiğini zihinde sürekli değerlendirme, aksayan yönleri zihinde sürekli değiştirme ve düzenleme becerilerine sahip olmayı gerektirir. Tüm bu zihinsel yeterlikler ve beceriler, düşünme süreçlerinin temelini oluşturmakta ve tüm düşünme boyutlarında bireyin o boyutun özelliğine göre düşünmesini sağlayan bir düşünme dili görevi görmektedir. Bu açıdan bilişsel farkındalık, hem düşünmenin temelinde yer almakta hem de düşünme becerilerinin tümünü içine almaktadır.

Temizkan (2009: 111), bilişsel stratejilerin okuma becerisinde kullanılmasını şu şekilde özetlemiştir; öğrencilerin en sık kullandıkları stratejilerden olan bilişsel stratejiler tekrardan, ifadelerin çözümlenmesine ve özetlenmesine kadar çok çeşitli adımları içermektedir. Bilişsel stratejilerin ortak amacı öğrenilen konunun, metnin öğrenci tarafindan düzenlenmesidir. Bilişsel stratejiler: yineleme, doğal olarak uygulama, düşünceyi çabuk algılama, iletiyi göndermek ve almak için kaynak kullanma, anlatımı çözümleme, çeviri, aktarım, not tutma, özetleme, işaretleme. 
Alkan’a (2000) göre eğitim sisteminin üç temel öğesi vardır; öğretmen, öğrenci ve eğitim programları. $\mathrm{Bu}$ öğeler içinde öğretmen, son derece önemli bir role sahiptir. Çünkü öğretmen, eğitim programlarını uygulayarak öğrencilerin belirlenen amaçlara ulaşması adına uğraş veren kişidir. Eğitimde öğretmen, eğitim etkinliklerinin düzenlenmesi ve yürütülmesinde özel bir öğretim uzmanı ve öğrenme yaşantıları yöneticisidir. Alkan, esasen eğitime anlam ve ruh veren, eğitimi işlevsel yapan, etkili ve verimli kılan temel öğenin öğretmen olduğunu ifade etmiştir (s. 21).

Okuma stratejileri bilişsel farkındalık becerileri öğrencilerin akademik ve sosyal hayatı için oldukça gereklidir. Bu becerileri kazandırmada da öğretmenlere büyük sorumluluk düşmektedir. Öğrencilerin "öğrenmeyi öğrenmeleri” kazanmaları gereken başlıca bilişsel becerilerdir. Bu becerilerin öğretiminde farklı yaklaşımlar olduğu görülmektedir. Fakat bu yaklaşımların hepsinde öğretmenlerin bilişsel farkındalık becerilerine sahip olmaları, kullanmaları ve öğretmek için ayrı çaba ve zaman harcamaları gerekmektedir.

\section{Amaç}

$\mathrm{Bu}$ çalışmanın amacı, Türkçe öğretmenlerinin öğrencilerin okuma stratejileri bilişsel farkındalık becerilerini geliştirmeye yönelik sınıf içinde ve sınıf dışında kullandıkları yöntem ve teknikleri belirlemek için görüşlerinin incelenmesidir.

\section{Araştırmanın Modeli}

\section{YÖNTEM}

Türkçe öğretmenlerinin okuma stratejileri bilişsel farkındalık becerilerini kullanma düzeylerini ve okuma-anlama eğitimine yönelik sınıf içinde ve sınıf dışında öğrencilere uyguladıkları yöntem ve teknikleri belirlemeye ilişkin bu araştırmanın yöntemi, olayları, olguları doğal koşulları içerisinde incelemeyi hedefleyen alan araştırması yöntemidir. Araştırmada tarama modeli kullanılmıştır. Tarama modeli, var olan bir durumu var olduğu şekliyle betimlemeyi amaçlar. Araştırmaya konu olan olay, birey ya da nesne, kendi koşulları içinde ve olduğu gibi tanımlanmaya çalışılır. Onları, herhangi bir şekilde değiştirme, etkileme çabası gösterilmez. Önemli olan, bilinmek istenen şeyin gözlenip, belirlenebilmesidir (Karasar, 2002: 77). Bu araştırmada yarı yapılandırılmış görüşme yöntemi kullanılmıştır.

\section{Çalışma Grubu}

Araştırmanın çalışma grubunu, Kars ili Millî Eğitim Bakanlığına bağlı ortaokullarda 2012-2013 yılında görev yapan Türkçe öğretmenlerinden 15 gönüllü öğretmen oluşturmaktadır.

Tablo 1.

Görüşme Yapılan Türkçe Öğretmenlerinin Demografik Özellikleri

\begin{tabular}{|c|c|c|c|c|}
\hline Öğretmen & Cinsiyet & Mezuniyet & $\begin{array}{c}\text { Kidem } \\
\text { yılı }\end{array}$ & Bölüm \\
\hline Ö1 & $\overline{\mathrm{K}}$ & $\begin{array}{l}\text { Yüksek } \\
\text { Lisans }\end{array}$ & 13 & Türkçe Öğretmenliği Anabilim Dalı \\
\hline Ö2 & $\mathrm{K}$ & Lisans & 15 & Türk Dili ve Edebiyatı Anabilim Dalı \\
\hline Ö3 & $\mathrm{E}$ & Lisans & 11 & Türkçe Öğretmenliği Anabilim Dalı \\
\hline Ö4 & $\mathrm{E}$ & Lisans & 14 & $\begin{array}{l}\text { Türk Dili ve Edebiyatı Öğretmenliği } \\
\text { Anabilim Dalı }\end{array}$ \\
\hline Ö5 & $\mathrm{E}$ & Lisans & 5 & Türkçe Öğretmenliği Anabilim Dalı \\
\hline Ö6 & $\mathrm{K}$ & Lisans & 6 & Türkçe Öğretmenliği Anabilim Dalı \\
\hline Ö7 & $\mathrm{K}$ & Lisans & 8 & Türkçe Öğretmenliği Anabilim Dalı \\
\hline Ö8 & $\mathrm{K}$ & Lisans & 8 & Türkçe Öğretmenliği Anabilim Dalı \\
\hline Ö9 & $\mathrm{E}$ & Lisans & 9 & Türkçe Öğretmenliği Anabilim Dalı \\
\hline Ö10 & $\mathrm{K}$ & Lisans & 3 & Türkçe Öğretmenliği Anabilim Dalı \\
\hline Ö11 & $\mathrm{K}$ & Lisans & 13 & Türkçe Öğretmenliği Anabilim Dalı \\
\hline Ö12 & $\mathrm{K}$ & Lisans & 12 & Türkçe Öğretmenliği Anabilim Dalı \\
\hline Ö13 & $\mathrm{K}$ & Lisans & 7 & Türkçe Öğretmenliği Anabilim Dalı \\
\hline Ö14 & $\mathrm{E}$ & Lisans & 17 & Türk Dili ve Edebiyatı Anabilim Dalı \\
\hline Ö15 & $\mathrm{E}$ & Lisans & 2 & Türkçe Öğretmenliği Anabilim Dalı \\
\hline
\end{tabular}

Veri Toplama Araçları 


\section{Türkçe Öğretmenleri için Yarı Yapılandırılmış Görüş̧me Formu}

Bu çalışmada veri elde etmek için kullanılacak görüşme formu hazırlanırken ilgili literatür taranmış ve okuma stratejilerinde kullanılan bilişsel farkındalık becerilerine yönelik "planlama, organizasyon ve değerlendirme" boyutlarını ortaya koymak üzere üç boyutta soru havuzu oluşturulmuştur. Ardından uzman görüşüne başvurulmuştur. Uzman görüşü için iki Türkçe Eğitimcisi ve üçü Eğitim Bilimlerinde olmak üzere beş kişiye görüş sorulmuştur. Bu çalışmalardan sonra iki öğretmenle pilot çalışma yapılıp öğretmenlerin de sorular hakkındaki görüşleri alınarak ve tekrar uzman görüşüne başvurularak görüşme formuna son şekli verilmiştir. Görüşme formunda 12 soru bulunmaktadır. (Eğitim-öğretim yılı başında öğrencilerin okuma düzeyini saptamak için herhangi bir çalışma yapıyor musunuz? Evet ise nasıl? Hayır ise neden? Açıklayınız.) Araştırmada veri toplama amacıyla standartlaştırılmış açık uçlu görüşme sorularından yararlanılmıştır. Standartlaştırılmış açık uçlu görüşme sorularının, tam olarak sırası ve tarzı önceden belirlenir, görüşme yapılan tüm kişilere aynı temel sorular aynı sıra ile sorulur, sorular tam anlamıyla açık uçlu bir formatta ifade edilir (Fraenkel ve Wallen, 2006, akt: Büyüköztürk ve diğerleri 2012: 153). Veri toplama aracı iki bölümden oluşmaktadır. Formun ilk kısmında katılımcıların kişisel özellikleri açısından betimlemek amacıyla araştırmacı tarafindan geliştirilen Kişisel Bilgi Formu kullanılmıştır. Formun ikinci kısımda ise görüşme soruları yer almaktadır. Yapılan görüşmeler 30 dakika ile 50 dakika arasında sürmüştür.

\section{Veri Toplama Süreci}

Görüşmeler, öğretmenlerin uygun oldukları bir saatte okul içinde boş derslikler, rehberlik odaları, kütüphane ve müdür odaları gibi gürültü ve kalabalığın olmadığı mekânlarda araştırmacı tarafindan birebir yapılmıştır. Görüşme esnasında öğretmenlerden izin alınarak ses kayıt cihazı kullanılmıştır. Görüşmeler yapılmadan önce araştırmanın konusu ve amacı araştırma grubundaki öğretmenlere açıklanmıştır. Bu şekilde on beş öğretmen ile görüşme yapilmıştır.

\section{Verilerin Analizi}

Araştırmada yapılan görüşmeler ses kayıt cihazıyla kaydedilmiştir. Bu kayıtlar hemen görüşme sonrasında, diğer görüş̧me yapılmadan önce bilgisayar ortamında yazıya aktarılmıştır. Ardından bu metinler içerik analizi yöntemiyle analiz edilmiştir. Araştırmaya katılan öğretmenlerin kimliklerini belirtmemek amacıyla isimleri farklı şekilde kodlanmış, gerçek isimleri gizli tutulmuştur. Görüşme verileri satır satır okunarak kodlar ve temalar oluşturulmuştur. Yapılan içerik analizi sonucunda kodlar ve temalar öğretmenlerin verdiği yanıtlardan çıkarılmış̧ır. Çıkarılan bu kodlar daha sonra belirlenen temalar altında gruplandırılmıştır. Bu işlemlere bir müddet ara verildikten sonra görüşme verileri tekrar okunmuş tema ve kodların son şekli verilmiştir. $\mathrm{Bu}$ çalışmada, sonuçlarının güvenirliğini sağlamak amacıyla iki önemli süreç gerçekleştirilmiştir. Birincisi veri analiz sürecinin (kavramsal kategoriye nasıl ulaşıldığı) detaylı bir şekilde açıklanması ikincisi ise araştırmada elde edilen kategorilere her biri için onu en iyi temsil ettiği varsayılan örnekler seçilerek bu örneklere bulgular kısmında yer verilmesidir. Diğer bir güvenirlik yöntemi olarak da, araştırmada ulaşılan kavramsal kategori altında verilen kodların söz konusu kavramsal kategorileri temsil edip etmediğini teyit etmek amacıyla birbirinden bağımsız iki araştırmacının kodları ve kodlara ilişkin kategorileri karşılaştırılmıştır. İki araşıtırmacının görüşlerinin karşılaştırılması sonucu elde edilen kodlayıcılar arası güvenirlik .85 (Güvenirlik=görüş birliği/görüş birliği+görüş ayrılı̆̆ı) olarak hesaplanmıştır (Miles ve Huberman, 1994). Ayrıca iki araştırmacı arasında görüş ayrılıklarının olduğu kodlar üzerine tartışılarak bahsi geçen kodlar uygun kategoriler altına yerleştirilmiş̧ir. Araştırmacılar arasında görüş birliği sağlanması amacıyla öğretmenlerin ifadelerini oluşturmalarındaki gerekçeler dikkate alınmıştır. Ayrıca her bir kodun frekansları ve yüzdeleri tablolar halinde sunulmuş bu doğrultuda bulgular yorumlanmıştır.

\section{BULGULAR}

$\mathrm{Bu}$ kısımda toplanan verilere iliş̧in bulgular yer almaktadır.

\section{Türkçe Öğretmenlerinin Sınıf İçi ve Sınıf Dışında Okuma-Anlama Eğitimine Yönelik Yaptıkları Plânlamalara İlişkin Bulgular}

Yarı yapılandırılmış görüşme formunda Türkçe öğretmenlerinin sınıf içi ve sınıf dışında okuma-anlama eğitimine yönelik yaptıkları planlamalar hakkındaki görüşlerini almak üzere 3 soru sorulmuş ve bu sorular ayrı temalar altında kodlanmıştır. 
Tablo 2.

Türkçe Ögretmenlerinin Sınıf Iç̧i ve Sınıf Dışında Okuma-Anlama Ĕgitimine Yönelik Yaptıkları Planlara Iliş̧kin Görüşleri ve Frekans Dă̆llımı

\begin{tabular}{llll}
\hline \multicolumn{2}{c}{ Tema } & \multicolumn{1}{c}{ Kodlar } & f \\
\hline Eğitim-öğretim & yılı & Zümre toplantılarında alınan kararlar & $\mathbf{8}$ \\
başında & yapılan & Millî Eğitimin verdiği hazır plânları kullanma & $\mathbf{6}$ \\
planlar & & Gerekli gördüğü yerde plâna ekleme çıarma yapma & $\mathbf{6}$ \\
& & Bir yıl önceki öğretmenlerin görüşlerine başvurma & $\mathbf{1}$ \\
& & Dönem başında zaman planlaması yapma & $\mathbf{1}$ \\
\hline & Toplam & $\mathbf{2 2}$ \\
\hline
\end{tabular}

Tablo 2'ye göre eğitim-öğretim yılı başında öğretmenlerin okuma-anlama eğitimine yönelik planlarının genel planlar içinde yer aldığı ve özel bir plân yapmadıkları görülmektedir. Öğretmenler, okuma-anlama eğitimine yönelik plânlamanın daha çok zümre toplantılarında alınan kararlar doğrultusunda şekillendiğini ifade etmişlerdir.

Dönem başında yapılan plânları belirlemek amacıyla sorulan soruya (Ö12) "Her dönemin başında, bildiğiniz gibi zümre toplantısı hazırlıyoruz. ... Ayrıca zümrenin dışında okuma-anlama etkinliklerine yönelik bir çalışma yapmıyoruz. Türkçe ögretmeni olarak bi kere 1. Aldığımız karar her sınıfin sinıf kitaplığının oluşturulmasını să̆lamak, sınıf öğretmeniyle işbirliğine gidilmeli ve bunu Türkçe öğretmeni mutlaka takip etmeli, sınıfin bir kitaplı̆̆ yoksa da Türkçe öğretmeninin öncülüğ̈̈nde bir sinıf kitaplı̆̆l oluşturulmalı ve her hafta bir ögrencinin bir kitap okuyup okumadı̆̆ takip edilmeli." şeklinde cevap vermiştir. Bu ifadeleriyle (Ö12) zümre toplantılarında alınan kararlar kodunda yer almıştır. Millî Eğitimin vermiş olduğu hazır planları kullandığını (Ö1) "Millî eğitimin verdiği hazır programın dışında özel olarak yaptı̆̆ım bir plân hazırlı̆̆ yok." Şeklinde ifade etmiştir.

Bununla birlikte (Ö4) "O kitaplara uyuyoruz ama ayriyeten eksik kaldığ yerlerde biz de ne yapıyoruz kendimize göre etkinlikler veya işte değişiklikler yapılması gerekiyorsa değişiklikler yapıyoruz. Mesela planı almış atıyorum Ankara için Anıtkabiri gezme ama biz bunu yapamayacă̆ımız için kendimize göre değişiklikler yapmak zorunda kalabiliyoruz." ifadesiyle gerekli gördüğü yerde plâna ekleme çıkarma yapma kodunda yer almıştır. (Ö10) ise "Plân olarak değil de ben her yıl aynı şeyi tekrarlamaktayım. Benden bir yıl önceki ögretmenlerin görüşlerini alıyorum. Şu öğrenci şu kadar, okuma seviyesi düşük, yüksek. Bu anlamda hani kendimi yönlendiriyorum, öğretmenin görüşleri doğrultusunda; plan olarak değil." ifadesiyle bir yıl önceki öğretmenlerin görüşlerine başvurma kodunda yer almaktadır. Dönem başında kendine bir zaman planlaması yapan (Ö14) görüşlerini şu şekilde ifade etmiştir: "Bu kazanımları alırım ondan sonra hangi üniteyi, temayı kaç günde bitiririm, onları hesaplarım, zaman planlamasını yaparım bu üç aşağı beş yukarı tutturmaya çalışırım.”

Türkçe öğretmenlerinin sınıf içi ve sınıf dışında okuma-anlama eğitimine yönelik ders öncesi yapılan hazırlıkları belirlemek amacıyla sorulan soruya verilen cevaplardan çıkarılan temalar, kodlar ve frekanslar tablo 3'te verilmiştir.

Tablo 3.

Türkçe Öğretmenlerinin Sınıf Iç̧i ve Sınıf Dışında Okuma-Anlama Eğitimine Yönelik Yaptıkları Ders Öncesi Hazırlık Aşaması Hakkındaki Görüşleri ve Frekans Dă̆ılımı

\begin{tabular}{lll}
\multicolumn{1}{c}{ Tema } & Kodlar & $\mathbf{f}$ \\
\hline & Metni okuma ve etkinliklere bakma & $\mathbf{6}$ \\
& Metnin durumuna göre araştırma yapma & $\mathbf{3}$ \\
& Aynı metinlerin olması, hazırlığa gerek duyulmaması & $\mathbf{3}$ \\
Ders öncesi & Alternatif metin seçme & $\mathbf{3}$ \\
yapılan ön & Bilinmeyen kelimelerin tespiti & $\mathbf{3}$ \\
hazırlıklar & Soru hazırlama & $\mathbf{2}$ \\
& Etkinlikler arasında seçim yapma & $\mathbf{2}$ \\
& Metinlerdeki eksiklikleri belirleme & $\mathbf{1}$ \\
& Kılavuz kitabı takip etme & $\mathbf{1}$ \\
& Bir sonraki konuyu takip etme & $\mathbf{1}$ \\
& Konuya benzer metinler bulma & $\mathbf{1}$ \\
& Haftalı ön hazırlık yapma & $\mathbf{1}$ \\
\hline
\end{tabular}

Bu konuda (Ö5) düşüncelerini şöyle ifade etmiştir: (Ö5)“'Iı okuma anlama etkinliklerine yönelik ders 
öncesi ön hazırlık kendim için, kendim başta metni güzel bir biçimde okuyorum. Kendim iyi anlamam lazım ki daha sonradan çocuklara da iyi aktarabileyim."

Yine yapılan ön hazırlıklar içinde metnin durumuna göre (Ö13) araştırma yaptığını şu şekillerde ifade etmiştir; "Naplyoruz işte okuyoruz önce ilk evde ben okuyorum sonra o konuya benzer hikâyeler, makaleler varsa yani düşünce yazısıysa düşünce yazısl, hikâyeler romanlarsa o tarz romanlar onların araştırmasını yapıyoruz sonra yazar hakkında bir araștırma yapıyoruz." Metinlerin her yıl aynı olması ve öğretmenlerin bu yüzden hazırlığa gerek duymaması ile ilgili (Ö2), şunları ifade ederek "Ben kendim yapıyorum zaten hani şey de var ya metinler hep belli metinler parçalar değişmiyor kaç yıldır. Yani metinleri de bildiğimiz için hani çok fazla hazırlı̆ga gerek kalmıyor, ezberledik çünkü.” Aynı metinlerin olması hazırlığa gerek duyulmaması kodunda yer almıştır.

Tablo 4.

Türkçe Öğretmenlerinin Eğitim-Öğretim Yllı Başında Öğrencilerin Okuma Düzeyini Belirlemek için Yaptıkları Çalışmalara İlişskin Görüşleri ve Frekans Dă̆gllımı

\begin{tabular}{lll}
\hline Tema & Kodlar & f \\
\hline & İlk girilen sınıflarda bütün öğrencilere metin okutma & $\mathbf{1 0}$ \\
& Okuma güçlüğ̈ olan öğrencileri belirleme ve özel tedbirler alma & $\mathbf{7}$ \\
& Ders içi ve dişı birebir çalışmalar, bireysel etkinlikler yapma & $\mathbf{6}$ \\
Okuma & Okuma gelişimini takip etme & $\mathbf{5}$ \\
düzeyini & Ailelerle işbirliği yapma & $\mathbf{5}$ \\
belirleme & Ders içi gözlem yapma & $\mathbf{4}$ \\
& Süreç içinde okuma düzeyini belirleme ve değerlendirme & $\mathbf{4}$ \\
& Okuması iyi olan öğrencileri öne çıarma ödüllendirme & $\mathbf{3}$ \\
& Genel seviye tespit sınavı & $\mathbf{2}$ \\
& Önceki yılla bağlantı kurma & $\mathbf{1}$ \\
\hline & Toplam & $\mathbf{4 7}$ \\
\hline
\end{tabular}

Öğretmenler, öğrencilerin okuma düzeyini belirlemek için ilk kez derslerine girdikleri sınıflarda bütün öğrencilere bir metin okuttuklarını ve bu şekilde okuma düzeylerini ortaya çıkardıklarını ifade etmişlerdir: (Ö4) "Illk girdiğimiz sinıflara ilk defa nedir mesela biz 5, 6, 7, 8'lere giriyoruz ya 5. sinıflarl aldik. İlk önce çocukların okuma seviyelerini tespit etmek için bir metni bütün öğrencilere okutuyoruz."

Öğretmenler okuma düzeyini belirlemek için yapılan çalışmalar ile ilgili görüşlerini; (Ö7) “Ölçeğimle değerlendiririm. Hani yutarak mı okuyor, net mi okuyor? Seviyesine uygun mu, değil mi, parmak takibi var mi, yok mu, okuduğunu anlayabiliyor mu hemen, ondan sonra da tedbir alınmast gereken çocuk varsa, okuma yazmayı hiç bilmeyen bir çocuk varsa ona yönelik ayrı bir tedbir alırım. Diğer gelişstirilmesi gerekenlere seviyelerine uygun, slklmayacakları kitaplar vermeğe çalışırım ki bazı çocuklar mesela okuduğunu pek anlayamıyor." şeklinde ifade ederek okuma güçlüğü olan öğrencileri belirleme ve özel tedbirler alma kodunda yer almıştır.

Yarı yapılandırılmış görüşme formunda, öğretmenlerin ders esnasında, okuma-anlama etkinliklerine başlamadan önce öğrenciye yaptırdıkları ön hazırlıklarla ilgili görüşleri alınmıştır.

Tablo 5.

Türkçe Öğretmenlerinin Ders Esnasında Okuma-Anlama Etkinliklerine Başlamadan Önce Öğrenciye Yaptırdıkları Ön Hazırlıklar Hakkındaki Görüşleri ve Frekans Dağıllımı

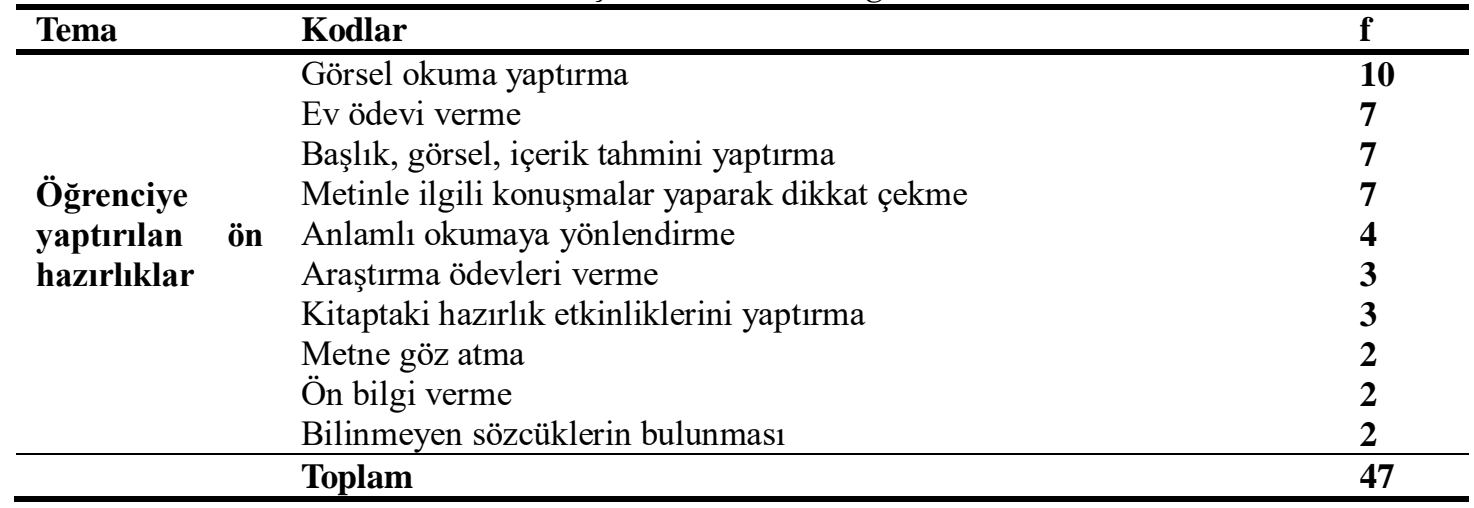


Öğretmenler ders esnasında okuma-anlama etkinliklerine başlamadan önce öğrencilere yaptırdıkları ile ilgili görüşlerinde en çok görsel okuma yaptırdıklarını belirtmişlerdir. Bu bağlamda görsel okuma kodunda yer alan bazı öğretmenlerin görüşleri şu şekildedir: (Ö2), "Ön hazırllk nedir, iște görselde ne gördün, ne anlatmak istiyor?.." (Ö4) "Mesela resim verilmiş, şu resimlerle ilgili neler söyleyebilirsiniz? Tarzında sorular olabiliyor." Bununla birlikte öğretmenlerin öğrencilere yaptırdıkları bir diğer çalışmanın ev ödevi olduğu belirlenmiştir. (Ö12) bu konudaki görüşünü şu şekilde ifade ederek ev ödevi verme kodunda yer almıştır; "Bazı parçalar, bazı demiyim, aslında artık maalesef çok çok uzun parçalar koymuşlar; bilmiyorum, incelediniz mi kitaplart? $\ddot{U}_{\zeta}$ sayfa dört sayfa yani çocuğun evde okumast şart, nasıl anliyabilecek ve çok ağır sıkıcı parçalar koymuşlar; bu tür parçalarda ev ödevi vermek zorunda kalyyorum." (Ö13) okuma öncesi yapılan etkinlikler için de görüşlerini şu şekilde; “...başlık veya metindeki görseller buradan bir yorum çıkarmaya çalışıyoruz, yani metinde ne anlatılyyor olabilir? Görsellerden yola çıkarak bir fikir diyoruz ya da başliktan yola çıkarak bir fikir üretiyoruz, ne anlatılabilir? Sinıfta bunu tahmin ediyoruz, sonra da hani metni okuduğumuzda da hangisi daha yakın, diye değerlendiriyoruz..." ifade ederek başlık, görsel, içerik tahmini yaptırma kodunda yer almıştır.

\section{Türkçe Öğretmenlerinin Sınıf İçi ve Sınıf Dışında Okuma-Anlama Eğitimine Yönelik Yaptıkları Uygulamalara İlişkin Bulgular}

Yarı yapılandırılmış görüşme formunda Türkçe öğretmenlerinin sınıf içi ve sınıf dışında okuma-anlama eğitimine yönelik yapmış oldukları uygulamalar hakkındaki görüşlerini almak üzere 5 soru sorulmuş ve her bir soru ayrı temalar altında kodlanmıştır.

Tablo 6.

Türkçe Öğretmenlerinin Okuma-Anlama Etkinlikleri Sirasında Öğrencilere Uygulattı̆̆ Okuma Stratejileri ile Ilgili Görüsleri ve Frekans Dăğlımı

\begin{tabular}{lll}
\hline Tema & Kodlar & $\mathbf{f}$ \\
\hline & Altını çizme & $\mathbf{9}$ \\
& Doğru ve anlamlı okumaya yönlendirme & $\mathbf{8}$ \\
Sesli okuma & $\mathbf{8}$ \\
Örnek okuma & $\mathbf{7}$ \\
Anahtar kelimeleri bulma & $\mathbf{6}$ \\
Sessiz okuma & $\mathbf{6}$ \\
Soru-cevap & $\mathbf{5}$ \\
Bölerek okuma & $\mathbf{5}$ \\
Sözcük çalışması yapma, sözlük kullanımı & $\mathbf{5}$ \\
& Tahmin ve tahminlerin doğruluğuna bakma & $\mathbf{5}$ \\
& Ana fikir ve yardımcı fikir bulma & $\mathbf{4}$ \\
Özetleme & $\mathbf{4}$ \\
Not alarak okuma & $\mathbf{4}$ \\
Tekrar okuma & $\mathbf{4}$ \\
Metran tamamlama & $\mathbf{3}$ \\
& Metni günlük hayatla ilişkilendirme & $\mathbf{3}$ \\
& Noktalama işaretlerine dikkat çekme & $\mathbf{3}$ \\
& Soru sorarak okuma & $\mathbf{3}$ \\
\hline
\end{tabular}

Öğretmenlerin okuma-anlama etkinlikleri sırasında öğrencilere uygulattığ stratejiler arasında en sık rastlananı altını çizerek okuma stratejisi olarak belirlenmiştir; (Ö2) “...parçada önemli neresi var, işte kahramanlarıyla ilgili bilgiler verilmiş mi? Onların altını çiziyor ya da yan karakterlerle ilgili var mı? Onların altını çiziyor." Ayrıca öğretmenler metni okurken öğrencileri anlamlı okumaya yönlendirmeye çalışmaktadırlar. $\mathrm{Bu}$ doğrultuda görüşlerini şu şekilde; (Ö7) "Ne çıkarması gerektiğini, ne sonuç çıkarması gerektiğini bilemiyorlar; bunların üzerinde nasıl çıkarmaları gerektiğini göstermeye çalışıyorum" ifade eden öğretmenler doğru ve anlamlı okumaya yönlendirme kodunda yer almışlardır. Bununla birlikte (Ö4) "Sesli okuma yaptırıyoruz, sesli yaptırmak hem çocuğun okumasın güzelleştiriyor; çünkü sessiz okuduğu zaman çocuk yanlış mı okudu, doğru mu okudu? Onun farkında değil ama sesli okuduğu zaman yanlış okuduğunu fark edebiliyor ögrenci; ona göre ne yapıyoruz, biz de düzeltiyoruz." şeklindeki ifadesiyle sesli okuma kodunda yer almıştır.

Tablo 7. Türkçe Öğretmenlerinin Okuma-Anlama Etkinlikleri Sirasında Öğrencilere Yaptırdıkları Görsel Okuma ile Ilgili Görüşleri ve Frekans Dağıllımı

\begin{tabular}{lll}
\hline Tema & Kodlar & f \\
\hline
\end{tabular}




\begin{tabular}{lll}
\hline & Metnin görsellerini yorumlama & $\mathbf{1 3}$ \\
& Görsellerle ilgili metin yazdırma & $\mathbf{5}$ \\
& Farklı görsellerden faydalanma & $\mathbf{5}$ \\
Görsel Okuma Çalışmaları & Görsel okumayı gereksiz ve vakit kaybı olarak görme & $\mathbf{3}$ \\
& Grafik, tablo ve afiş çalışması yaptırma & $\mathbf{3}$ \\
& Çevredeki görselleri yorumlama ve hikâyeleştirme & $\mathbf{1}$ \\
\hline & Toplam & $\mathbf{3 0}$ \\
\hline
\end{tabular}

Öğretmenler okuma-anlama etkinlikleri sırasında genellikle metnin görsellerini öğrencilere yorumlattıklarını şu şekilde ifade etmişlerdir; (Ö11) “...sınavlarda soru çıkıyor artık, resim veriliyor, resimden soru soruyorlar; o yüzden bizim kitaplarımızda da var zaten. Çocuklara diyoruz ki bu resmi ilk gördüğünüzde aklınıza ne geldi, ne düşündünüz bu resmi ilk gördüğünüzde ve ya size ne çağrıştırdı, ne hatırlattı bu resim?.. (Ö14) "Görsel okuma metni çözümlemenin yarısıdır. ... Çok önemlidir, çocuk ona bakacak, 'yavrum bu metinden ne anlyyorsun?' metne bakacak çocuk, ha şöyle şöyle bir şey var zaten, işte o resimleri yorumladiğında görsel daha çabuk yorumlaniyor, daha çok dikkat çekiyor." (Ö15) "Görsel okuma bazen şöyle ki parçaya başlamadan önce parçanin resimlerini inceletiyorum, 'hani bu metinlerden sizce anlatılmak istenen nedir?' diye veya -ne anlatılıyor, ne anlıyorsunuz?- gibi sorular sorarak bu şekilde görsel okuma yaptırabiliyorum."

Tablo 8.

Türkçe Öğretmenlerinin Öğrencilere Ders Dışı Yaptırdıkları Okuma-Anlama Etkinlikleri ile İlgili Görüşleri ve Frekans Dă̆glımı

\begin{tabular}{lll}
\hline Tema & Kodlar & $\mathbf{f}$ \\
\hline & Roman, hikâye okutma & $\mathbf{8}$ \\
& Ailelerle iş birliği sıkıntısı ve ailelerin olumsuz tutumları & $\mathbf{8}$ \\
& Özet çıkartma ve sınıfta değerlendirme & $\mathbf{7}$ \\
& Ailelerle iş birliği yapma & $\mathbf{6}$ \\
Ders dışında & Evde aileyle birlikte kitap okuma saatleri düzenleme & $\mathbf{5}$ \\
yapılan okuma- & Performans ödevleri verme & $\mathbf{4}$ \\
anlama & Kütüphaneye yönlendirme & $\mathbf{3}$ \\
etkinlikleri & Ögrencilere kitap temin etme & $\mathbf{3}$ \\
& Bir ders saatini okumaya ayırma & $\mathbf{2}$ \\
& Okuma güçlüğü olan öğrencilerle çalışma yapma & $\mathbf{1}$ \\
\hline
\end{tabular}

Öğretmenlerin, öğrencileri ders dışında okumaya sevk etmek için yaptıkları en önemli etkinlik olarak evde kitap okutmak olduğunu belirtmişlerdir. (Ö1) "Yani ders dışında en fazla kitap okuyoruz, hani normal kitap okunuyor." Öğretmenlerin büyük bir kısmı da öğrencilerin aileleriyle iş birliği yapmanın zorluğundan bahsederek ailelerle iş birliği sıkıntısı ve ailelerin olumsuz tutumları kodunda şu şekilde görüş belirtmişlerdir; (Ö6) "Çoğu ailelerde şöyle bir şey var, biz öğrencilerden de şunu çok duyuyoruz; mesela kitap okuyun diyoruz evde, çok fazla işte, şey diyorlar, kitap okuduğumuz zaman aileler şey diyor işte 'ders çalışsana okumaya zaman ayıracağına' diye, ailelerde de yanlış bir görüş var." "şeklinde cevap vererek ailelerle yaşadıkları sıkıntıları ve ailelerin okumanın önemini kavramadıklarını ortaya koymaktadır. (Ö10) ise görüşlerini: "Ailelerimiz pek ilgili değil çünkü kendileri okumuyor. O yüzden ailelerle pek iletişim yok." şeklinde dile getirerek ailelerle iş birliğinin zorluğundan bahsetmiştir. Öğretmenlerden bazıları da evde okudukları kitapların özetlerini çıkarttırdıklarını ve bu özetleri sınıf içinde değerlendirdiklerini belirterek "özet çıkartma ve sınıfta değerlendirme" kodunda yer almışlardır; (Ö5) "Çocuklar işte bu kitapların özetlerini çıkarıyorlar. Gerçekten okuyup okumadıklarını anlamak için biz onlara bu okudukları kitapları anlatmalarını, kitaptan ne anladıklarını anlatmalarını istiyoruz."

Tablo 9.

Öğretmenlerinin Öğrencilere Okuma Alışkanlı̆̆ Kazandırmak için Yaptırdıkları Etkinlikler ile Ilgili Görüşleri ve Frekans Dă̆glımı 


\begin{tabular}{llc}
\hline \multicolumn{1}{c}{ Tema } & \multicolumn{1}{c}{ Kodlar } & $\mathbf{f}$ \\
\hline & Kitap okutma ve değerlendirmesini sınıf içinde yapma & $\mathbf{8}$ \\
Okuma & Öğrencinin ilgisine göre kitap seçme & $\mathbf{3}$ \\
alışkanlığı & Okumaya mecbur tutma, not verme & $\mathbf{3}$ \\
kazandırmak & Bir ders saatini okumaya ayırma & $\mathbf{3}$ \\
için $\quad$ Öğrenciye örnek olma & $\mathbf{3}$ \\
etkinlikler & Sinava yönelik çalışma & $\mathbf{2}$ \\
& Bu alanda kendini yetersiz görme & $\mathbf{2}$ \\
& Araştırma ve performans ödevleri verme & $\mathbf{2}$ \\
& Olumlu tutum geliştirmeye çalışma & $\mathbf{2}$ \\
& Ödüllendirme & $\mathbf{2}$ \\
& Kütüphaneye yönlendirme & $\mathbf{2}$ \\
\hline
\end{tabular}

Öğretmenlerin büyük bir kısmı kitap okuma alışkanlığı kazandırmak için öğrencilere kitap okuttuklarını ve bu kitapların değerlendirmesini sınıf içinde yaptıklarını dile getirmişlerdir; (Ö6) "Tabi ki, kitap isimleri de yüz temel eserden onları tavsiye ediyorduk, onun dışında mutlaka okudukları kitabı getirip göstermelerini istiyorduk. Gerçekten okudular mı, okumadılar mı? Ve dediğim gibi ben sınıfta mutlaka anlattırıyorum, mesela, diyorum, bir ay süreniz var, bir ay sonra, 'Ayşe sen hangi kitabı okudun?' Bize gel bi anlat diye, o şekilde okuma yaptırıyorum. Kitap mutlaka okutturuyorum; okuduysan hani bize anlat, yazar kimdi, ne anlatıliyordu, beğendin mi, nasıl buldun kitabını? Eleştirisini mutlaka yaptırıyorum çocuklara."

Öğrencilere kitap okuma alışkanlığı kazandırmak için sadece üç öğretmen öğrencinin ilgisine göre kitap seçimi kodunda görüş belirtmiştir; (Ö9) "Okuma alışkanlı̆̆ı kazanabilmesi için bireyin yeteneklerini bulabilmek önemli. Bireyin yeteneklerini keşfedebilmeli, ona göre oluyor, yani tek tip öğrenci merkezli bir sonuç vermiyor; yani işte aman çocuk okusun, pahalı kitapları önüne koymak çocuğa bir yararı yok. Veya çocuk sevmiyorsa sürekli klasikleri çocuğa hediye vermenin bir anlamı yok, çocuk için bir zahmet. Çocuğun yeteneklerini keşfedip ona göre doğru yönlendirmek lazım. Tiyatroyla ilgileniyorsa tiyatro ile ilgili kitaplar, sporla ilgileniyorsa spor gazetesi önüne konulabilmeli."

Tablo 10.

Türkçe Öğretmenlerinin Öğrencilerin Söz Varlıklarını Geliştirebilmeleri için Yaptırdıkları Etkinlikler ile İlgili Görüşleri ve Frekans Dă̆llımı

\begin{tabular}{lll}
\hline Tema & Kodlar & $\mathbf{f}$ \\
\hline & Sözlük oluşturma & $\mathbf{8}$ \\
& Oyunlarla kelime öğretimi & $\mathbf{6}$ \\
& Yeni kelimelerle hikâye veya metin yazdırma & $\mathbf{5}$ \\
& Deyim ve atasözü buldurma & $\mathbf{5}$ \\
Söz $\quad$ varlıklarını & Kelimelerin farklı anlamlarını buldurma & $\mathbf{5}$ \\
geliştirebilmeleri için & Kelime tekrarları yaptırma & $\mathbf{4}$ \\
yapılan etkinlikler & Sözlük kullanma & $\mathbf{4}$ \\
& Bilinmeyen kelimenin altını çizdirme & $\mathbf{3}$ \\
& Kelime türetme & $\mathbf{2}$ \\
& Günlük tutturma & $\mathbf{1}$ \\
& Bulmaca çözme & $\mathbf{1}$ \\
& Sinıf panosuna kelimeler asma & $\mathbf{1}$ \\
& Günlük kelime havuzu oluşturma & $\mathbf{1}$ \\
\hline
\end{tabular}

Öğretmenler, öğrencilerin söz varlıklarını geliştirmek için en çok sözlük oluşturma etkinliği yaptıklarını şu cümlelerle ifade etmişlerdir; (Ö15) “...sözlük oluşturduk, o sözlükten not verdiğimiz için ögrenciler sözlüğe bayağı ilgi duydular; sonra sözlük okumalar gelişti ögrencilerin, bunu fark ettim..." (Ö4) "Mesela sözlük hazırlatıyoruz, söz dă̆arcıklarını geliştirmek amacıyla bu tarzda çalışmalarımız oluyor."

Yine öğretmenler çeşitli oyunlarla öğrencilerin söz varlıklarını geliştirme çalışmalarını şu şekilde dile getirmişlerdir; (Ö6) “Tabu oyunumuz var kelimelerle ilgili, onu oynatıyoruz." (Ö3) "Yarış yapıyoruz, kim erken bulacak işte o şekilde kelimeleri mesela sürekli tekrarliyoruz ögrendiğimiz kelimeleri; işte çocuklara kelime zimmetliyoruz. Bak şu şudur, bir dahaki ders geldiğinde mutlaka soruyorum; işte "çamçak" neydi falan çocuk kalkıp söylüyor.” Öğretmenler bu ifadelerle "oyunlarla kelime öğretimi” kodunda yer almışlardır. 
Sözlük oluşturmanın ve oyunlarla kelime öğretiminin yanı sıra öğretmenler, öğrencilere yeni kelimelerle hikâye ve metin yazdırarak onların söz varlıklarını geliştirmeye çalışmaktadırlar. (Ö7) "yeni kelimelerle hikâye veya metin yazdırma" kodunda görüşlerini şu şekilde belirtmiştir; “...anlamını bilmedikleri kelimelerin altını çizdiriyorum, daha sonra o kelimeleri tahtaya yazıyoruz, ıı onların anlamlarını bulduruyorum, metindeki anlamlarını, daha sonra bunlarla ilgili attyorum; on kelime, on beş kelime en az on tanesini kullanarak bir paragraf yaz, bunu yazdiriyorum..."

\section{Türkçe Öğretmenlerinin Sınıf İçi ve Sınıf Dışında Okuma-Anlama Eğitimine Yönelik Yaptıkları Değerlendirme Yöntemlerine İlişkin Bulgular}

Yarı yapılandırılmış görüşme formunda Türkçe öğretmenlerinin sınıf içi ve sınıf dışında okuma-anlama eğitimine yönelik yapmış oldukları değerlendirmeler hakkındaki görüşlerini almak üzere 3 soru sorulmuş ve her bir soru ayrı temalar altında kodlanmıştır.

\section{Tablo 11.}

Türkçe Ögrretmenlerinin Okuma-Anlama Ekinlikleri Sonunda Öğrencilere Öz Değerlendirme Yaptırma Hakkindaki Görüşleri ve Frekans Dağılımı

\begin{tabular}{llc}
\hline Tema & Kodla & $\mathbf{f}$ \\
\hline \multirow{2}{*}{$\begin{array}{l}\text { oz değerlendirme } \\
\text { olumlu }\end{array}$} & Etkinlik kitabındaki öz değerlendirme formlarını uygulama & $\mathbf{6}$ \\
& Öz değerlendirmeyi faydalı bulma & $\mathbf{2}$ \\
& Yazılı kâğıtlarını öğrencilere dağıtma & $\mathbf{1}$ \\
\hline & Toplam & $\mathbf{9}$ \\
\hline \multirow{2}{*}{$\begin{array}{l}\text { Öz değerlendirme } \\
\text { olumsuz }\end{array}$} & Öğrencilerin isteksiz oluşu ve objektif olmaması & $\mathbf{5}$ \\
& Formları gereksiz görme & $\mathbf{4}$ \\
& Zamanın yetmemesi & $\mathbf{3}$ \\
& Ölçekleri yetersiz bulma & $\mathbf{1}$ \\
\hline & Toplam & $\mathbf{1 3}$ \\
\hline
\end{tabular}

Öğretmenlerin, öz değerlendirme yaptırma hakkındaki görüşlerini almak üzere sorulan soruya, altı öğretmenin etkinlik kitaplarındaki öz değerlendirme formlarını uyguladıkları yönünde görüş belirttiği tespit edilmiştir. (Ö8) "Evet, bununla ilgili zaten kilavuz kitaplarında, çalışma kitaplarında, elimizde etkinlikler var; orda kendini değerlendirme formu, arkadaşını değerlendirme formları var. Çocuklar onları dolduruyorlar."

Öğretmenlerin bir kısmı öz değerlendirme hakkında olumlu görüş belirtirken bir kısmı da olumsuz görüş belirtmiştir. Olumsuz görüş belirten öğretmenlerin sayısı, olumlu görüş belirten öğretmenlerin sayısından fazladır. Öğretmenlerin beşi "öğrencilerin isteksiz oluşu ve objektif olmaması” kodunda görüş belirtmiştir. (Ö11) "Yani çok yaptığım söylenemez, şunu söyleyeyim sanki o tür etkinliklerde çocuk çok ciddiye almiyor çarpı koyup geçme. Hiç kimse kendisinde yanlış var, hata var, demiyor. Çok iyi okudum; evet, arkadaşımınkini de çok iyi anladım, bir sorun yok, şeklinde olumlu cevaplar geliyor sürekli. Öğretmenlerden dördü ise öz değerlendirmeyi gereksiz gördüğünü belirtmiştir. (Ö5) "Öz değerlendirme yaptırmıyorum. Hani okumanı yeterli buluyor musun, neden? Yaptırmiyorum, yani hiç, bilmem, gereksiz gördüğüm için...”

(Ö3) ise zamanın yetersiz olduğunu ve bu tür etkinliklere vakit kalmadığını şu şekilde dile getirmiştir; (Ö3) "Vakit kalmıyor, çok sıkıntıll; yani ne verilecek, ne verilmeyecek onların derdine düsüyorsunuz, yetişmiyor; şudur budur bu konular çok kağıt üstünde yapllyyor ama yani öyle öz değerlendirme falan çok havada kalan bir şey."

Tablo 12.

Türkçe Öğretmenlerinin Okuma-Anlama Becerilerini Değerlendirme Süreci Hakkindaki Görüşleri ve Frekans Dağılımı

\begin{tabular}{|c|c|c|c|}
\hline Tema & & Kodlar & $\mathbf{f}$ \\
\hline \multirow{10}{*}{$\begin{array}{l}\text { Etkinlikleri } \\
\text { süreci }\end{array}$} & \multirow{10}{*}{ değerlendirme } & Yazilı sinavlar & 11 \\
\hline & & Süreçte değerlendirme & 8 \\
\hline & & Okuma değerlendirme formları olumsuz & 8 \\
\hline & & Okuma değerlendirme formları olumlu & 4 \\
\hline & & Kendi değerlendirme yöntemlerini kullanma & 3 \\
\hline & & Kompozisyon yazdırma & 3 \\
\hline & & Özet defterleri tutturma & 2 \\
\hline & & Okuma gelişim dosyaları & 2 \\
\hline & & Performans ödevleri & 2 \\
\hline & & Toplam & 43 \\
\hline
\end{tabular}


Öğretmenlerden on biri, okuma-anlama etkinliklerini değerlendirme sürecinde yazılı sınavları kullandıklarını belirtmişlerdir. (Ö4) "Değerlendirmeleri genellikle yazıllya göre yapıyoruz, zaten işte eğer yazllida problem varsa atıyorum, \%50'den daha az başarısızsa o konuları tekrar etme yoluna gidiyoruz, tekrar ediyoruz." (Ö5) "Ya yazılılar dışında yok yani. Mesela, yazılıda bir parça sorumuz oluyor, metin sorumuz oluyor. Ona verdiği cevabl değerlendiriyoruz." Yine öğretmenlerden sekizi değerlendirme sürecinde soru-cevap yöntemini kullanarak süreçte öğrencileri değerlendirdikleri yönünde görüş belirtmiştir. (Ö1) "İşte ben en çok o anllk soru cevaplarla hani onu nasıl anladı?.." Öğretmenlerin çoğunluğu okuma değerlendirme formları hakkında olumsuz görüş bildirmişlerdir; (Ö5) "Ya bizim okumayla ilgili kullandı̆̆ımız yöntemler genelde kendiliğinden gelişen yöntemlerdir. Mesela yani özel bir yazıya dökülmüş yöntemler kullanmam lazım, değerlendirirken bunu yapayım, özel bununla ilgili bir programım yok."

Tablo 13.

Türkçe Öğretmenlerinin Okuma Sonrasında Okuma Metninin Anlaşılma Durumunu Görmek için Yaptırdıkları Etkinliklere İlişkin Görüssleri ve Frekans Dağllımı

\begin{tabular}{|c|c|c|}
\hline Tema & Kodlar & $\mathbf{f}$ \\
\hline \multirow{10}{*}{$\begin{array}{l}\text { Okuma metninin } \\
\text { durumu }\end{array}$} & Soru-cevap & 11 \\
\hline & Özet yaptırma & 8 \\
\hline & Ana fikir -yardımcı fikir buldurma & 5 \\
\hline & Metni anlattırma & 5 \\
\hline & Kitaptaki etkinlikleri yaptırma & 5 \\
\hline & Soru hazırlatma ve karşılıklı sordurma & 4 \\
\hline & Metin üzerinde tartışma yaptırma & 2 \\
\hline & Tekrar okuma & 2 \\
\hline & Metnin analizini yaptırma & 2 \\
\hline & Toplam & 44 \\
\hline
\end{tabular}

Öğretmenlerden on biri okuma sonrasında metnin anlaşılma durumunu görmek için soru-cevap yöntemini kullandıklarını belirtmişlerdir; (Ö9) "İşte şöyle yine burada anlatılmak istenen ne ulı siz olsaydınız neler yapabilirdiniz? Bir yazarın yerine siz olsaydınız daha farklı mı bağlardınız? Burada verilmek istenen mesaj ne? Mesaja uygun mu bağlanmış? Ya da mesaja göre mi sonuca bağlanmış? Şeklinde sorular soruluyor." Soru-cevap yönteminden sonra karşımıza en çok özet yaptırma yöntemi çıkmaktadır. (Ö4) "....metnin durumuna göre, metne göre özetlenmesi gerekiyorsa hadi çocuklar bunu özetleyelim o tarzda; en sonunda da işte ne şekilde özetlenmesi gerekiyorsa onu anlattyoruz." Bununla birlikte öğretmenlerden beşi "ana fikir -yardımcı fikir buldurma" kodunda görüş belirtmişlerdir. (Ö1) "İște okuma sonrasında, biz okuma sırasinda hep bunu yapıyoruz; sonra ana fikir ve yardımcı fikir kavramın anlatmaya çalışlyorum işte. Tamam, bir tane ana fikir bulduk..."

\section{SONUÇ VE TARTIŞMA}

Calp'e (2007: 12) göre ne kadar mükemmel programlar hazırlanırsa hazırlansın programın öngördüğü hedeflerin gerçekleşme başarısı öğretmenin çabalarına bağlıdır. Bu bakımdan öğretmenin çabası sistematik ve planlı olmalıdır. Bu çerçevede öğretmenlerin neyi, niçin, nasıl, nerede, ne zaman yapacağını bilmesi ve sürdürmekte olduğu eğitim-öğretim etkinliklerinin nasıl değerlendirileceğine ilişkin bilgi, beceri ve alışkanlıklara sahip olması önemlidir.

Tüm bu anlayışlar dikkate alındığında, öğretmenlerin dönem başında mutlaka bir plân yapması gerektiği görülmektedir. Ayrıca öğretmenin, bu planın zaman dağılımını yapmasının yanında yapılan bu plân üzerinde yıl içinde bulunulan bölgenin, okulun, sınıfın hatta öğrencinin durumuna göre gerekli gördüğü yerde değişiklikler yapması gerekmektedir. $\mathrm{Bu}$ araştırmada plânlama aşaması öğretmenlere sorulduğunda, öğretmenlerin plânlamaya gerektiği kadar önem vermedikleri, genellikle verilen hazır plânları kullandığı ve plân dışına çok fazla çıkmadığı görülmüş̧ür.

Okuma amacına ve içinde bulunulan koşullara göre okuma teknikleri birtakım farklılıklar göstermektedir. Bu özellikler dikkate alınarak öğrencilere amaca göre okuma becerisi kazandırılmalıdır. Okuma becerisi bireyin kendini geliştirmesi ve hayatta ilerleyebilmesi açısından çok önemlidir. Okuma sadece okul öğrenmelerinde değil hayatın her alanında gereklidir. Bu nedenle okuma eylemi anlama gücüyle desteklendiği zaman amacına ulaşmıştır, diyebiliriz. Özer'e (2002: 51) göre, okuduğunu anlama ve yazma becerilerinin 
geliştirilmesinde öğrenme stratejilerini kullanma yoluyla öğrenciler, kendi öğrenmeleriyle ilgili olarak bilinçli öğrenici durumuna gelebilir, öğrenmedeki verimliliği artırabilir, bağımsız öğrenebilme becerisi kazanabilir, isteyerek ve zevk alarak öğrenebilirler. Bu çalışmada, öğretmenlerin en çok kullandığı okuma stratejisi olarak "altını çizme" karşımıza çıkmaktadır. "Altını çizme, öğrencinin kendisinde var olan bilgiyle yeni bilgi arasında ilişki kurmasını sağlar. Özellikle önemli bilgiyi önemsizden ayırt etmede öğrencinin daha önce kazanmış olduğu şemalar rol oynar" (Senemoğlu, 2005: 560).

Topçuoğlu Ünal ve Yeğen (2013) çalışmalarında öğretmenlerin en skk kullandıkları yöntemin sesli okuma ve ikinci olarak da sessiz okuma yöntemi olduğunu, okuma tiyatrosu ve ezberleme yöntemlerinin ise öğretmenler arasında en az kullanılan yöntem olduğunu tespit etmişlerdir. Bu çalışmada da sesli okuma ve sessiz okuma yöntemlerinin öğretmenlerin en fazla görüş bildirdiği yöntemlerden olduğu görülmektedir. Öğretmenler farklı birçok kodda görüş belirtmişlerdir. Yapılan uygulamaların bu kadar çeşitli olması olumlu bir durumken öğretmenlerin aynı kodlarda görüş bildirmemesi yapılan uygulamaların birlik ve bütünlük sağlamadığını göstermektedir. Örneğin; metinler arası bağlantı kurma, işaretleyerek okuma, doğaçlama yaptırma, grup çalışması, söz korosu ve diğer yöntemlerin frekansları oldukça düşüktür.

Çalışmada, görsel okuma hakkında olumsuz görüş bildiren öğretmenler olduğunu görmekteyiz. Bu da öğretmenlerin bir kısmının görsel okumayı önemsiz gördügüünü fakat müfredat gereği uyguladıklarını göstermektedir. Çam (2006) çalışmasında görsel okuma ile okuduğunu anlama becerisi, eleştirel okuma becerisi ve Türkçe dersi akademik başarıları arasında anlamlı bir ilişki bulmuştur. Ancak bu çalışmada öğretmenlerin büyük bir kısmının bu faydaları görmezden geldiği ve görsel okumayı önemsiz bulduğu ortaya çıkmaktadır.

Öğretmenlerin kelime öğretiminde kullandıkları metotların hepsi alan yazında tavsiye edilen metotlardandır. Ancak bu uygulamalarda öğretmenler arasında bir birlik olmadığı gibi öğretmenlerin bireysel olarak geliştirdiği sistematik uygulamalar da yoktur. Bilinçli, sistematik, bütünsel bir yaklaşımla uygulanmadığı için seçilen yöntemin doğru olması sözcük öğretimi açısından yeterli olacağı anlamına gelmemektedir.

Okuma sonrasında, iyi okuyucu; aldığı notları da kullanarak metinle ilgili yorumlar ve özetlemeler yapmaktadır. İlk izlenimlerinin ve düşüncelerinin gelişim ve değişimini zihinsel süzgeçten geçirerek yeni anlama ulaşma şeklini bir kez daha düşünür. Öğretmenin okuma sonrasında öğrencinin bu düşüncelerini ortaya çıkarması gerekmektedir. Bunun için birçok etkinliği birlikte kullanmak; öğrencinin okuduğunu anlayıp anlamadığını ortaya çıkarmak açısından önemlidir. Görüşmeler sonucunda öğretmenlerin metnin anlaşılma durumunu görmek için en çok görüş belirttiği kod "soru-cevap"tır. Yapılan literatür çalı̧̧malarında da öğretmenlerin en çok kullandıkları değerlendirme stratejisi olarak soru-cevap ve soru oluşturma yöntemi karşımıza çıkmaktadır. Yıldırım (2012) ve İnce' nin (2012) çalışmaları bu çalışmayı destekler niteliktedir. Yıldırım'ın (2012) çalışmasında "soru üretme" boyutunu öğrenme-öğretme ortamlarında kullanma düzeyleri ortalamalarından elde edilen bulgular neticesinde; öğretmenlerin "soru üretme" boyutunu yüksek düzeyde kullandıkları belirlenmiştir. Yine İnce'nin, öğretmenler üzerinde yaptığı bir çalısmasında, okuma sonrası en çok kullanılan stratejinin soruları yanıtlama olduğu tespit edilmiştir. Bu sonuçlardan hareketle sorucevap stratejisinin en sık kullanılan strateji olduğu söylenebilir.

Joseph (2010, s.99-103) araştırmasında, üst biliş ile ilgili bilgileri incelemiş ve yayınlamıştır. Bu bilgiler ışı̆̆ında orta ve yüksek öğretim öğretmenlerine; öğrencilerin üst bilişsel becerilerinin gelişimlerini göz önünde bulundurarak bazı önerilerde bulunmuştur. Joseph'e göre birçok öğretmen öğrencilerin üst bilişsel becerilerini geliştirmeye çalışır. Fakat öğretmenlerin de bu becerilere tam olarak sahip olmadığı görülmektedir.

Araştırma sonuçlarına göre Türkçe öğretmenlerinin öğrencilerin okuma stratejileri bilişsel farkındalık becerilerini geliştirmeye yönelik sınıf içinde ve sınıf dışında etkinlikler yaptıkları fakat öğrencilere bilişsel farkındalık becerilerini kazandıracak yeterlilikte olmadığı görülmüştür. Duffy ve Miller (2009), öğretmenlerin bilişsel farkındalık stratejilerini uygulama aşamasında yaşadıkları sorunlar üzerine hazırladıkları çalışmada, yaşanan üç temel sorundan bahsetmektedirler. Birincisi terminolojik sorunlar; öğretimde bilişsel farkındalık ve bilişsel becerisinin yeri neresidir? İkincisi duruma bağlı sorunlar; öğretmenler, karmaşık ve çok boyutlu bir öğretim süreci içerisinde bilişsel farkındalık becerisini kullanabilir mi? Ve son olarak ise metodolojik sorunlar; öğretmenler bilişsel farkındalık becerisine ne oranda sahiptirler? Soruları öğretmenlerin bilişsel farkındalık stratejilerini uygulama esnasında yaşadıkları temel sorunlar olarak tespit edilmiştir. Sonuç olarak eğitimde yenilenme yolu tercih edilerek; öğretim yöntemlerinin, öğretim stratejilerinin, personel geliştirmenin ve denetim süreçlerinin bilinçli olarak tasarlanması gerekmektedir. Ancak böylece bilişsel farkındalık becerisini yaşam tarzı 
haline getirecek bireyler yetiştirilebilir. Çalışmada elde edilen sonuçlara göre şu önerilerde bulunmak mümkündür:

Hazırlanan eğitim programı ve planlarında öğrencilerin bilişsel farkındalık becerilerini fark ettirmeye ve kullandırmaya yönelik öğretim etkinliklerine ve uygulamalarına ağırlık verilmelidir.

Öğretmenlere görsel okuma, okuma stratejileri, alternatif ölçme yöntemleri ve öz değerlendirme hakkında hizmet içi eğitimler verilmesi sağlanmalıdır.

Ders kitaplarında öğrencilerin okuma stratejileri bilişsel farkındalık becerilerini geliştirecek metinlere yer verilmesi sağlanmalıdır.

Öğretmenlerin bilişsel farkındalık düzeylerini kullanmaları üzerine deneysel çalışmalar yapılmalıdır.

\section{KAYNAKLAR}

Alkan, Cevat (2000). Bilimsel, Ulusal ve Evrensel Boyutlu Öğretmenlik Mesleği. Öğretmenlik Mesleği Türkiye-Almanya ve Kıbris'ta Öğretmen Yetiştirme. (Ed. Hasan Coşkun), Ankara: CTB Yayınları.

Aytaş, Giyasettin (2003). Okuma gelişiminde çocuk edebiyatının rolü. Türklük Bilimi Araştırmaları, Niğde, (13), 155-160.

Bamberger, Richard (1990). Okuma Allşkanlı̆̆ıı Geliştirme. (Çev: Bengü Çapar). Ankara: Kültür Bakanlığı.

Büyüköztürk, Şener, Kılı̨̧ Çakmak, Ebru, Akgün, Özcan Erkan, Karadeniz, Şirin ve Demirel, Funda (2012). Bilimsel Araştırma Yöntemleri. (11. Baskı) Ankara: PegemA Yayıncılık.

Demirel, Funda (2012). Bilimsel Araştırma Yöntemleri. (11. Baskı) Ankara: PegemA Yayıncılık.

Duffy, G.G. ve Miller, S. (2009). Teachers As Metacognitive Professionals. Hacker, D. J., Dunlosky, J. ve Graesser, A.C. (Ed.), Handbook of Metacognition In Education, (s.240-256). NY: New York.

Epçaçan, Cevdet (2009). Okuduğunu anlama stratejilerine genel bir bakış. Uluslararası Sosyal Araştırmalar Dergisi, 2 (6).

Calp, Mehrali. (2007). Özel Öğretim Alanı Olarak Türkçe Öğretimi. (3. Baskı), Konya: Eğitim Kitabevi.

Çam, Bilge (2006). İlköğretim Öğrencilerinin Görsel Okuma Düzeyleri ile Okuduğunu Anlama, Eleștirel Okuma ve Türkçe Dersi Akademik Başarıları Arasındaki İlişki, Yüksek Lisans Tezi, Eskişehir Osmangazi Üniversitesi Sosyal Bilimler Enstitüsü, Eskişehir.

Doğanay, Ahmet (1996). Öğrenmenin boyutları: birleşik bir öğretim modeli. Çukurova Üniversitesi Eğitim Fakültesi Dergisi, 2(14), s. 48-54.

Gelen, İsmail (2003). Bilişsel Farkındalık Stratejilerinin Türkçe Dersine İlişkin Tutum, Okuduğunu Anlama ve Kalıcllğa Etkisi, Doktora Tezi, Çukurova Üniversitesi Sosyal Bilimler Enstitüsü, Adana.

İnce, Yasemin (2012). Sinıf Öğretmenlerinin Türkçe Derslerinde Kullandlkları Okuduğunu Anlama Stratejileri, Yüksek Lisans Tezi, Ușak Üniversitesi Sosyal Bilimler Enstitüsü, Ușak.

Joseph, Nancy (2010). "Metacognition needed: Teaching middle and high school students to develop strategic learning skills." Preventing School Failure: Alternative Education for Children and Youth, 54 (2): 99103.

Karasar, Niyazi (2002). Bilimsel Araştırma Yöntemleri (Kavramlar, İlkeler, Teknikler). Ankara: Nobel yayınları.

Miles, B. Matthew and Huberman, M. A. (1994). Qualitative data analysis. London: Sage Publication.

Özer, Bekir (2002). İlköğretim ve ortaöğretim okullarının eğitim Programlarında Öğrenme Stratejileri, Eğitim Bilimleri ve Uygulama, 1 (1): 17-32.

Senemoğlu, Nuray (2005). Gelişim Öğrenme ve Öğrenme Kuramindan Uygulamaya. Ankara: Gazi Kitapevi.

Temizkan, Mehmet (2009). Metin Türlerine Göre Okuma Eğitimi. Ankara: Nobel Yayınları.

Topçuoğlu Ünal, Fulya ve Yeğen, Ümit (2013). Türkçe öğretmenlerinin okuma yöntem-tekniklerini ve araç-gereçlerini kullanma durumları, Turkish Studies, 8(4): 1351-1365.

Türk Dil Kurumu (2011). Türkçe Sözlük, Ankara: Türk Dil Kurumu Yayınları.

Yıldırım, Nuray (2012). Öğretmenlerin Öğrenme-Öğretme Ortamlarında Bilișsel Farkindallk Stratejilerini Kullanma Düzeyleri, Yüksek Lisans Tezi, Firat Üniversitesi Eğitim Bilimleri Enstitüsü, Elazığ. 


\section{EXTENDED SUMMARY}

\section{INTRODUCTION}

The main purpose of reading is to understand what you read and to improve your ability to understand in this way. However, a series of cognitive process is required to provide understanding. Reading techniques show some differences in accordance with the purpose of reading and the conditions. Reading skill should be brought to students based on purpose by considering these features. Inferring the exact and accurate meaning from the text read constitutes the basis for the learning at school. Effective reading is considerably important in terms of comprehending and learning the content of academic materials. Individuals read and understand various written materials in school and social lives. Understanding what is read at simple level, finding the main idea in limited number, summarizing and findings answers to similar questions remain insufficient to achieve the level of reading desired.

\section{PURPOSE}

The aim of this study is to analyze the views of Turkish teachers for determining the methods and techniques they use inside and outside the classroom to improve the students' cognitive awareness skills of reading strategies.

\section{METHOD}

The method of this study, which is aimed to determine the methods and techniques applied to the students by the Turkish teachers inside and outside the classroom for the levels of using cognitive awareness skills of reading strategies and reading- comprehension education, is a field research method, intending to examine the events and cases in their natural conditions. Survey model was used in this study. The semistructured interview method was also used in the study. The texts obtained from the interviews were analyzed by using content analysis method. The sample group of the study consisted of 15 voluntary Turkish teachers working in school year of 2012 and 2013 in secondary schools affiliated with Ministry of National Education, in the province of Kars.

\section{FINDINGS}

When the Turkish teachers were asked about their views on the plans they made for the readingcomprehension education inside and outside the classroom, it was observed that the decisions taken during the class meetings were mostly effective during the term. (T12) "As you know, we prepare the class meeting at the beginning of each term. ... We do not make a work for the reading comprehension activities other than the class." The code on reading texts and looking at the activities in accordance with the Turkish teachers' views on pre-lesson preparation stage for reading-comprehension education inside and outside the classroom had the highest frequency. The teachers stated that they had all the students read a text in the classes they had taught for the first time in order to determine the students' reading level, and by this way they revealed their reading level: (T4) "The first thing to do in the classes we teach for the first time, for example, we teach the 5th, 6th, 7th, and 8 th grades, take the 5th grade. We have all students read a text at first in order to determine their reading level." In their views about activities they request from students to make before they begin the reading-comprehension activities during the lesson, they stated that they had the students make visual reading at most. In that sense, the views of some teachers in the visual reading code were as follows: (T2), "What is preliminary preparation, then what did you see in the visual and what meaning is it trying to convey?" During the reading-comprehension activities, the most frequently encountered one among strategies applied to the students by the teachers was found to be the reading strategy with highlight; (T2) "....what is the most important part of the text, then is any information given about the characters? They underline, or is it related to the side characters? They underline again." In addition, the most significant activity carried out by teachers to encourage their students to read outside the classroom was to have students read book at home: (T1) "I mean the thing we can do at most outside the classroom is to read a book, the usual book." A great majority of the teachers stated that they had their students read books in order to have them gain the habit of reading books and they carried out assessment of these books in the classroom; (T6) "Of course, we recommended the ones among the hundred main works; except for this, we always asked them to show the book they read." It was found from the question asked to take teacher's views on self-assessment; six teachers stated that they applied the self- assessment forms in the activity books. (T8) "Yes, we have already activities in the guidebooks, workbooks and in our hand; there are selfassessment form, friend evaluation form. The students fill them in."

Eleven of the teachers stated that they used the written exams during the process of assessing reading- 
comprehension activities. (T4) "We make the assessments usually based on the written exam, and if there is already a problem in the written exam, let me say, if the rate of success is below $50 \%$, then we revise and repeat those topics."

\section{CONCLUSION AND DISCUSSION}

According to Calp (2007: 12), no matter how perfect a curriculum is prepared, the success of realizing the objectives foreseen by the curriculum depends on the teacher's efforts. In this regard, the effort of the teacher should be systematic and planned. When considering all understandings, it is anticipated that teachers need to make a planning absolutely at the beginning of the term. When the teachers were asked about the stage of planning in this study, it was observed that the teachers did not attach necessary importance on planning, they used usually the prepared plans and they did not go beyond them. Topçuoğlu Ünal and Yeğen (2013) found in their study that the most frequently used method by the teachers was oral reading method, and secondly silent reading method; whereas, the least used method was reading theatre and memorization methods. In this study, it was observed that silent reading and oral reading methods were among the methods they stated mostly opinions for. Teachers expressed their views on many codes. Given that much variety of practices is a positive situation, but the fact that teachers did not express their views in the same codes indicated that there was no unity and coherence among the practices carried out. It was observed that there were teachers expressing negative views on visual reading. This revealed that some of the teachers considered visual reading unnecessary but they applied it due to the curriculum. In the study of Çam (2006) a significant correlation between visual readings and comprehension skill, and between critical reading skill and Turkish lesson academic success was found. However, in this study it was revealed that a majority of teachers ignored these benefits, and they considered visual reading insignificant. All the methods used by the teachers for vocabulary teaching are the ones suggested in the literature. However, there was no unity in such practices among the teachers, and also there were no systematic practices developed individually by teachers either. As it was not applied with a conscious, systematic, and holistic approach, it does not mean that the selected correct method would be sufficient for vocabulary teaching. According to the results of the study, it was observed that the Turkish teachers carried out activities inside and outside the classroom to improve the students' cognitive awareness skills of reading strategies but these activities were insufficient. 